\title{
The Missile Technology Control Regime (MTCR), International Power Relations and International Law- making
}

\author{
Dikjiratmi \\ \{dikjiratmi@lapan.go.id\} \\ Universitas Paramadina, Indonesia \\ Center for Aerospace Policy Studies, LAPAN, Indonesia
}

\begin{abstract}
The MTCR is a multilateral non-proliferation regime that regulates exports and imports of dual-use technology among its member countries. This paper examines the connection between MTCR and power relations between countries and the formation of international law. The theory used is Mieville commodity-form theory through descriptivequalitative method. Based on research conducted, MTCR is an instrument using by several developed countries to dominate international space development while limiting the opportunities of other countries, including Indonesia, to obtain the technology. MTCR's rule is not an international treaty, it is not an internationally binding law but it has a huge impact on the international technology import regulations making process.
\end{abstract}

Keywords: Dual-Use, Power, Space, Export and Import, International Relations, International Law

\section{Introduction}

The development of space technology and applications has had a number of consequences in the international political map. It must be admitted that the scale of the space capabilities of a number of countries greatly influences their political position in the international world. Space capability can be seen as an element of national power. This condition cannot be separated from the nature of the dual-use space technology. Space technology basically used for peaceful purposes. The first goal of space exploration is for the development of science. In line with the developments, space technology, especially the launch vehicle, could be used as a weapon of mass destruction given by its ability to reach hundreds to thousands of kilometers range. Launch vehicle may be defined as a vehicle used to send one or several payloads into earth's orbit. From this consideration, space launch vehicle (SLV) could be categorized as a weapon of mass destruction (WMD) and its proliferation must be controlled.

Based on the thought to control the proliferation of the SLV as WMD, The Missile Technology Control Regime (MTCR) came up. MTCR initiated by several countries who believe that the export and import of SLV and its components must be controlled by a multilateral regime. This regime, MTCR, received various criticisms, especially from space activities late-comer countries because of the difficulties it made for these countries to obtain space technology. The MTCR has generated many legal and political debates around the world.

It is widely recognized that the construction of international law is greatly influenced by the international political map. International law not only regulates legal phenomena in relations 
between countries but is also closely related to relations between states, between non-state actors, or between state actors and non-state actors. The dynamics in the relations between these actors will greatly influence the development and application of international law. Furthermore, international law is diverse, the same as international politics. There are several approaches that can be used to figure out the connection between international law and international politics. The MTCR could be used as an example on how international politics influences the international law making.

\section{Method}

The research method used is descriptive-qualitative research method carried out by doing literature studies trough exploring data and information related to MTCR using primary and secondary data sources. The primary data source was obtained from the MTCR website. Secondary data sources are books and scientific journals. Creswell [1] explains that the research method is a research plan and procedures that include steps in the form of assumptions extensive to detailed methods of studying, analysis and interpretation data and it really depends on text and image data, unique analysis steps. Descriptive research is describing the actual situation about the object with the data collected is not numeric (numbers). The analysis carried out by applying the commodity-form theory perspective. This perspective will be further elaborated in later section.

\section{Result and Discussion}

\subsection{Commodity-Form Theory}

One of the thoughts that is quite powerful in international politics is Marxism. The group of thought that was initiated by Marx was based on the class struggle, this thought views the world as classified between the capitalist class and the working class. In particular, Marx did not discuss the formation of international law. Marx's fundamental thought is about the economy, how the working class should deal with the capitalist group [2].

In its development, the application and thought of Marxism was expanded by a number of experts, including in understanding the development of international law. One of the pioneers of this development was Pashukanis [3], a Marxist thinker from the Soviet Union. Pashukanis [3] pioneered the idea that international law is another form of commodity exchange in which groups of commodity owners face groups of workers. Pashukanis [3] believes that the commodity form logic has the same substance as the legal form logic.

Pashukanis followed by Mieville [4], who wrote "Between equal rights: a Marxist theory of international law". In this book, Mieville [4] put many attentions on the commodity-form element. He also put some important concepts on how to understand the relations between international law and international relations based on commodity-form perspectives which is originated from the Pashukanis [3] thought with several modifications. Mieville [4] put forth the defense that mercantilism can best be perceived as a structure momentary to capitalism. The main purpose behind building up this contention is that it shows that the detachment of economic and political issues - the market and coercive savagery isn't constitutive to capitalism, and that the inclination toward it is set about by countertendencies. The economic and political matters could be perceived as the commodity in the international law. 
Mieville [5] contends that some imperialism activities are outlined in juridical terms. It is not only for the propagandist reasons, however more essentially on the grounds that imperialism and international law works in a similar framework. On this case, the international law has the same form as the global capitalism, lead into global imperialism [5].

Still according to Mieville [5], countries in the world can serve two interests, whether to become sovereign states based on their own strength or to support domination in the region or in the world. Traditionally, the United States has held this position of dominance for decades. In Mieville's [5] understanding, there is no international authority that can act as a conflict mediator and no institution has the legal authority to be able to use violence as a monopoly effort to enforce international law. The coercion tools are owned by the state which controls the capacity for coercive violence which in the international system is not distributed equally [6].

\subsection{Multilateral Export Control and Non-Proliferation Regimes}

Currently, there are 6 (six) multilateral export control and non-proliferation regimes, namely the Wassenaar Arrangement, the Hague Code of Conduct, the Nuclear Suppliers Group, the Australia Group, the Zangger Committee and the Missile Technology Control Regime.

Each of the multilateral regimes has its own controlled items, conventional weapons, nuclear items, biological weapons, and ballistic missile. They have their own regulations the members also vary. The similarity between all of the regime is that they try to prevent the weapon, conventional and non-conventional, from being transferred easily. The MTCR is the only regime that as kits members to put the regime regulations into each member national law.

\subsection{The MTCR}

Historically, MTCR comes from the United States President's policy on November 1982 which was called National Security Council Directive 70 which among others, contains about proliferation of nuclear missiles [7]. The MTCR was formed in April 1987 with the aim of preventing the proliferation of launch vehicles and their components from being used as weapons of mass destruction. MTCR regulates that all member countries do not transfer spacecraft or parts thereof to other countries or parties with technological limitations that have a minimum range of 300 kilometers. A number of countries in the 90 s destroyed their ballistic weapons systems or stopped their ongoing programs with the aim of making it easier for them to become members of the MTCR. They hope that becoming a member of the MTCR will get the ease of transferring more sophisticated technology. These countries include Brazil, Czech, Poland, Argentina, Egypt and Iraq. During its development, not all of them succeeded in becoming members of the MTCR given the strict terms and conditions that must be approved by all existing members.

Each MTCR member is required to include all rules and lists of controlled items in the MTCR Annex into their respective national laws. The list of items is dynamic. In each MTCR meeting, all members can propose to add or remove certain items by consensus of all members. The items that are controlled are divided into two categories. Namely categories I and II. Category I is the main category that contains all parts of the rocket and rocket as a whole. Items on this list are rarely allowed to be exported. While Category II contains items that can be used for civilian purposes, the MTCR still requires member countries to make very strict considerations for the transfer of these items.

Today, MTCR has 35 members: Argentina, Australia; Austria; Belgium; Brazil; Bulgaria; Canada; Czech Republic; Denmark; Finland; France; Germany; Greece; Hungary; Iceland; India; Ireland; Italy; Japan; Luxemburg; Netherlands; New Zealand; Norway; Poland; Portugal; 
Republic of Korea; Russian Federation; South Africa; Spain; Sweden; Switzerland; Turkey; Ukraine; United Kingdom; United States of America. Several space faring countries are not members of MTCR, namely China, Iran, and North Korea.

The MTCR Members believe that by joining the regime, they have been preventing the world from the WMD proliferation threat. They also believe that they have set the worldwide norm to prevent the dual-use technology being extensively developed. The multilateral norm that builds by the MTCR thus being international standard to guide the non-proliferation initiatives. The members also benefited from the discussion and cooperation conducted by the regime [8].

Continuously, the MTCR using several indicators when evaluating an object possible transfer. It consists of the end-user intention; the objectives and skills of the missile and the program; the proposed capacity contribution should be carried out for the improvement of the weapon receiving weapon delivery system intended for the user; the user credibility; and the multilateral agreements conformity. MTCR members always asked to get the user guarantee that the item they will import will only be used as stated in the contract. The user, or the recipient, should also make the end-user statement where they pledged not to transfer the item or its replica or its derivative to a third party without permission.

MTCR is voluntary based and the choice to transfer the technology based on each member country assessment. But on the other hand, the United States as a pioneer of MTCR has rules to impose sanctions, politically and economically, for all parties, both state and non-state that transfer goods that are included in the MTCR control list to parties that according to American rules are included in the national and international security blacklist. Transfers can also be subject to prohibition if they are deemed contrary to the MTCR rules. Sanctions could include a ban on receiving aid or buying weapons from America for a period of two years or longer.

The MTCR can be said to discriminate against countries outside this regime. However, under international law, it is legal. This is appropriate with the provisions of the Law of Treaties, the Vienna Convention 1969, which adheres to principle (Pacta terties nec nosent nec prosunt) that is, an agreement does not cause rights and obligations towards third parties who are not members. As well known, MTCR only strictly prohibits its members to do transfer of technology to the nonmember countries [9].

From the commodity-form perspective, MTCR is a clear example of unequal power relations between countries that have power and those that do not. Mastering of space launch technology becomes the power used by MTCR to discriminate other countries by not allowing them to obtain such technology through export and import restrictions on equipment and components that are included in the MTCR rules. The MTCR has huge influence on its members export regulations which consequently affects the international relations between its members and other countries.

The MTCR rules, known as MTCR Guidelines, adopted by its members on their national regulations. Formally, the MTCR does not have the authority to impose its sanctions on any violations. The country members are the one who does. The United States did it many times. Again, and again, the US dominates this world.

On the other hand, mastering ballistic missile technology has been being many developing countries national interest. Those technology is the key to outer space technology which is the technology of the future. Its dual use characteristic could also be used to increase any countries military capabilities. Rocket main function is to send satellite or any other payloads into orbit, but it is easy to convert into inter-continental ballistic missile

Theoretically, all countries may apply MTCR control guidelines into its national regulations but that does not mean that all countries can become members of the MTCR. MTCR supports the idea that the transfer or export and import of space launch technology that is included in their export control list is limited to fellow MTCR members. Let see China. China has declared that it 
follows MTCR rules in dual-use technology transfer issue, but this does not necessarily make China free to trade controlled items with the MTCR member countries because China is not a member of the MTCR. Indonesia may also state that it will follow all MTCR guidelines or may already include these guidelines in its national export import regulations. However, because Indonesia is not a member of the MTCR, Indonesia still cannot obtain the technology. The MTCR is widely known as depends on the dominance of the United States. The United States has a national policy that only countries that have bilateral agreements with the United States could be treated as partners. Whether a country can obtain space technology or not will depend on whether it has a bilateral agreement with America or not. A similar policy is then implemented in all MTCR member countries. Under these conditions, the MTCR is no more like a tool used by imperialist countries to prevent the late comer countries from developing the space technology. As Mievile said, that imperialist action is framed in juridical terms. The MTCR showing that the relations between those who have power (i.e. technology) and those who do not have will remain unequal and will never be equal by using its guidelines as the instrument.

\section{Conclusion}

The MTCR is the only regime on dual-use ballistic missile technology which its guideline should be included into its member's national export control policy. The guidelines itself has very detail list of controlled items that also has to be included. It discriminates other countries who do not have the technology. From the above analysis, it could be concluded that the MTCR is another form of imperialist actions using the export control regime as in the commodity-form theory wrote by Mieville. Ultimately, the MTCR is nothing more than a power relationship between countries that is very unequal.

\section{References}

[1] J. W. Creswell and J. D. Creswell, Research design: Qualitative, quantitative, and mixed methods approaches. Sage publications, 2017.

[2] A. Saad-Filho, The Value of Marx Political Economy for Contemporary Capitalism. Routledge, 2002.

[3] E. B. Pashukanis, "Law and Marxism: a general theory," 1978.

[4] C. Mieville, "Between Equal Rights: A Marxist Theory of International Law," 2005.

[5] C. Mieville, "The Commodity-Form Theory of International Law: An Introduction," Leiden J. Int. Law, vol. 17, pp. 271-302, 2004.

[6] S. Marks, "International Judicial Activism and the Commodity-Form Theory of International Law,” Eur. J. Int. Law, vol. 18, no. 1, 2007.

[7] E. Susilawati, Suatu Pemikiran tentang Kepentingan Indonesia terhadap MTCR. 1997.

[8] Bureau of International Security and Nonproliferation, "Missile Technology Control Regime (MTCR) Frequently Asked Questions," 2017.

[9] Mardianis, "Missile Technology Control Regime (MTCR) Dalam Kerangka Sistem Pelarangan Penyebaran Senjata Perusak Massal," J. Anal. dan Inf. Kedirgant., vol. 4, no. 1, pp. 1-13, 2007. 